\title{
СТАТИСТИЧНИЙ ПОРІВНЯЛЬНИЙ МІЖГРУПОВИЙ АНАЛІЗ ПОЄДНАННЯ ГЕНОТИПІВ
}

\author{
В. З. Стецюк, Т. П. Іванова ${ }^{3}$, А. Й. Савицький, 3. І. Россоха², А. О. Остапова \\ Конструкторське бюро інформаційних систем Національного технічного університету \\ України «Київський політехнічний інститут» \\ Державний заклад «Референс-центр з молекулярної діагностики Міністерства охорони \\ здоров'я України»² \\ Національна дитяча спеціалізована лікарня «ОХМАТДИТ» Міністерства охорони здоров'я \\ України ${ }^{3}$
}

\begin{abstract}
У повідомленні розглянуто проблему автоматизації молекулярної діагностики пацієнтів із генетичними захворюваннями в Україні, основні їі переваги та недоліки. Запропоновано спосіб спрощення обчислення та статистичного аналізу поєднання генотипів. У статті розглядається програмний комплекс для проведення розрахунків, створений для закладу «Референс-центр з молекулярної діагностики Міністерства охорони здоров'я України». Програмне забезпечення цього комплексу складається з двох частин, які націлені на виконання двох основних функцій працівників закладу для проведення статичних обчислень. Описано методи та інструменти, що були використані при створенні програмного комплексу.
\end{abstract}

Ключові слова: автоматизація, обчислення, програмний комплекс, статистичний аналіз, порівняння, генотип.

\section{СТАТИСТИЧЕСКИЙ СРАВНИТЕЛЬНЫЙ МЕЖГРУППОВОЙ АНАЛИЗ СОЧЕТАНИЯ ГЕНОТИПОВ}

\author{
В. З. Стецюк, Т. П. Иванова ${ }^{3}$, А. Й. Савицкий, 3. И. Россоха ${ }^{2}$, А. А. Остапова \\ Конструкторское бюро информационных систем Национального технического \\ университета Украины «Киевский политехнический институт» \\ Государственное учреждение «Референс-центр по молекулярной диагностике \\ Министерства здравоохранения Украины»² \\ Национальная детская специализированная больница «ОХМАТДЕТ» Министерства \\ здравоохранения Украины ${ }^{3}$
}

В сообщении рассмотрена проблема автоматизации молекулярной диагностики пациентов с генетическими заболеваниями в Украине, основные ее недостатки и преимущества. Предложено метод упрощения вычислений и статистического анализа сочетания генотипов. В статье рассматривается программный комплекс для вычислений, созданный для учреждения «Референс-центр по молекулярной диагностике Министерства здравоохранения Украины». Программное обеспечение этого комплекса состоит из двух частей, которые направлены на выполнение основных функций сотрудников для проведения статистических вычислений. Описаны методы и инструменты, которые были использованы при создании программного комплекса.

Ключевые слова: автоматизация, вычисления, программный комплекс, статистический анализ, сравнение, генотип.

\section{COMPARATIVE STATISTICAL ANALYSIS OF GENOTYPES' COMBINING}

\section{Z. Stetsyuk, T. P. Ivanova ${ }^{3}$, A. Y. Savitskyi, Z. I. Rossokha ${ }^{2}$, A. O. Ostapova}

Design Office of Information Systems in National Technical University of Ukraine «Kyiv Polytechnic Institute»

State Institution "Reference Center for Molecular Diagnostics of Ministry of Public Health of Ukraine"2

National Children's Specialized Hospital «OKHMATDYT» of Ministry of Public Health of Ukraine ${ }^{3}$

An important consequence of informatization of medical professionals is to decrease the number of diagnostic errors, large long-term calculations, to improve the accuracy of calculations.

(с В. 3. Стецюк, Т. П. Іванова, А. Й. Савицький, 3. І. Россоха, А. О. Остапова 
The program was designed to make calculations and statistical analysis of the genotypes' combination for the institution «Reference Center for Molecular Diagnostics of Ministry of Public Health of Ukraine».

The program provides the creation of desktop program complex for statistics calculations on a personal computer of doctor. Modern methods and tools for development of information systems were described to create program.

Key words: avtomatization, computing, program complex, statistical analysis, comparison, genotype.

Вступ. Сьогодні в умовах науково-технічного прогресу все більш актуальним $є$ впровадження інформаційних технологій в медицині, що означає використання інформаційних систем, за допомогою яких стає можливим здійснення швидких обчислень необхідних параметрів та доступ до інформації медичними працівниками.

С багато проблем, які потребують вирішення за рахунок впровадження інформаційних систем в розпорядок роботи медичних працівників.

Важливим наслідком інформатизації роботи медичних працівників $є$ зменшення кількості помилок у розрахунках, скорочення часу на здійснення обчислень, підвищення точності розрахунків.

Мета дослідження - спрощення обчислень та аналізу поєднання генотипів працівниками Референсцентру з молекулярної діагностики Міністерства охорони здоров'я України (далі Референс-центр) за рахунок створення обчислювальної бази.

Матеріал і методи дослідження. Для вирішення поставленої задачі, а саме для здійснення статистичного порівняльного міжгрупового аналізу поєднання генотипів, була створена програма для Референсцентру. Першим етапом роботи було вивчення предметної області та вхідної інформації. В ході дослідження було проаналізовано медичну документацію.

Результати й обговорення. Програма передбачає створення на персональному комп'ютері співробітника Референс-центру обчислювальної бази.

Одна з основних цілей, яка стоїть перед лікарем генетичного відділення в процесі його роботи - це здійснення великої кількості обчислень щодо порівняння поєднання генотипів. Як правило, масив вхідної інформації складається з великої кількості значень.

\section{Література}

1. Г. Шилдт, С\# 4.0: полное руководство. : пер. с англ. - М. : ООО «И.Д. Вильямс», 2011.-1056 с. : ил.

2. М. Е. Фленов, Библия С\#.-СПб. : БХВ-Петербург, 2009.560 с. : ил.
На даний час всі обчислення проводяться комбіновано: перша частина вручну, друга - за допомогою складних ресурсоємних програм.

Розроблювана система за своїм призначенням складається 3 двох частин: обчислення існування певного гену (поєднання генів) у деякої кількості людей, що поділені на дві групи, друга частина - проведення статистичного аналізу.

Методи вирішення задачі. Для створення програми були застосовані сучасні засоби та інструменти розробки інформаційних систем. До таких засобів належить продукт Microsoft Visual Studio - сучасне потужне середовище для розробки програмного забезпечення. Даний продукт дозволяє розробляти програми 3 графічним інтерфейсом, в тому числі 3 підтримкою технологіï Windows Form. За допомогою цієї технології було розроблено простий та зручний інтерфейс користувача, що дуже важливо враховувати в роботі медичного працівника. Принцип роботи програми - одновіконний, тобто виконання функцій передбачає те, що користувач буде залишатись в межах одного вікна. Програмний код написаний за допомогою високорівневої мови програмування С\#.

Слід відзначити простоту користування програмою, тобто немає необхідності в спеціальній підготовці лікаря для виконання вищеописаних завдань.

Висновки. Проаналізувавши функції даної системи можна сказати, що впровадження такої програми значно полегшить роботу медичного працівника та надасть великі переваги, серед яких особливо необхідно виділити зменшення кількості помилок у розрахунках, скорочення часу на здійснення обчислень, підвищення точності розрахунків, простота використання програми без додаткового навчання працівників.

3. Э. Троелсен, Язык программирования С\# 2008 и платформа .NET 3.5 4-е изд.: пер. с англ. - М. : ООО «И.Д. ВильяМС), 2011. -1344 с. : ил.

4. Нойес Б. Привязка данных в Windows Forms : пер. с англ. - М. : ООО «Бином-Пресс», 2009. - 632 с. : ил. 